\title{
RELATIONSHIP OF THE MOISTURE CONTENT OF FINNISH WHEAT FLOUR AND RELATIVE HUMIDITY
}

\author{
Yu-Yen Linko and PekKa Linko \\ Research and Development Laboratories, Vaasan Höyrymylly Osakeyhtiö \\ Helsinki, Finland
}

It is generally known that flour moisture content varies with the relative humidity of air. The relative humidity at which a product, at a given temperature, neither gains nor loses moisture is called equilibrium humidity. If the equilibrium humidity is lower than the atmospheric relative humidity, the moisture content of the product tends to increase, and vice versa. Although the moisture relationships of different cereal grains are similar (Coleman and Fellows 1925), the adsorption and desorption isotherms of cereal flours are not the same. Thus different samples of same flour in equilibrium with the same atmospheric relative humidity may have a different moisture content (BABBIT 1949). The equilibrium moisture levels of flour are higher during desorption than during adsorption, a phenomenon called hysteresis. Therefore, the moisture loss during drying may be gained back only at a relative humidity higher than the original.

The relationship of the moisture content of wheat flour and relative humidity, as obtained by several workers (ANDERsson 1937, ANker et al. 1942, BAILEy 1920, FAIRBRother 1929), is summarized below:

\begin{tabular}{ccccrr}
$\begin{array}{c}\text { Relative } \\
\text { humidity }\end{array}$ & Bailey & Fairbrother & Anderson & \multicolumn{2}{c}{ Anker $-e t$ al. } \\
$\%$ & & & & $25^{\circ} \mathrm{C}$ & $37 \mathrm{C}^{\circ}$ \\
30 & 5.2 & 9.4 & & 9.7 & 8.5 \\
40 & 6.5 & 9.7 & & 11.1 & 9.9 \\
50 & 8.0 & 10.7 & 12.0 & 12.3 & 11.1 \\
60 & 9.8 & 12.8 & 13.7 & 13.2 & 12.3 \\
70 & 12.1 & 14.0 & 15.4 & 14.5 & 13.7 \\
80 & 15.0 & 15.7 & & 16.3 & 15.8 \\
90 & & 16.7 & & &
\end{tabular}


It appears that the equilibrium humidity of flour of $14 \%$ moisture is about $65 \%$, that of flour of $15 \%$ moisture about $70 \%$, and that of flour of $16 \%$ moisture about $75 \%$. The latter corresponds to that portion of the isotherm where relatively large quantities of "free" water are believed to become available to activate various grain enzymes and to be utilized by micro-organisms (Linko 1960). Thus, in practice, cereal products in equilibrium with relative humidities of $75-80 \%$ or higher may be expected to deteriorate rapidly at normal storage temperatures.

Although the relative humidity varies considerably in different parts of Finland, the monthly averages obtained from the measurements at various air port locations during ten years indicate relatively low monthly average humidities during the warm summer months:

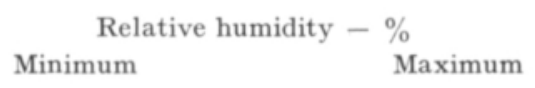

$\begin{array}{lll}\text { January } & 87 & 92 \\ \text { February } & 84 & 89 \\ \text { March } & 77 & 84 \\ \text { April } & 71 & 79 \\ \text { May } & 64 & 71 \\ \text { June } & 64 & 70 \\ \text { July } & 70 & 76 \\ \text { August } & 77 & 82 \\ \text { September } & 81 & 86 \\ \text { October } & 86 & 90 \\ \text { November } & 89 & 93 \\ \text { December } & 88 & 93\end{array}$

During winter, the relative humidity in warehouses and storage rooms equipped with central heating may, for long periods, stay as low as $20-30 \%$. It may therefore be expected that flour of original moisture content of $15 \%$ would tend to lose moisture during normal storage, and no special package appears necessary to prevent moisture migration. However, certain special cereal products, such as some types of prepared cake mixes, may have equilibrium humidity values as low as $30 \%$ requiring a carefully chosen package to prevent a possible increase in moisture (BORCHARDT 1950). The purpose of the present study was to obtain information on the changes in moisture content of commercial Finnish wheat flour during storage at different relative humidities.

\section{Materials and methods}

A typical commercial Finnish wheat flour packed in standard $1000 \mathrm{~g}$ paper bags was chosen for the object of study, since the possible variations in flour moisture and net weight are greatest in a relatively small package. The average moisture content of flour at the time of packing was $15 \%$. Several samples of flour were stored in a warehouse at normal conditions, with a monthly check of the moisture content and a continuous recording of the relative humidity and temperature. Other samples were stored in air-tight glass chambers equipped with a fan and a hygrometer. The relative humidity was adjusted by means of water solutions of sulphuric acid. The 
observed relative humidity ranges in various chambers were $32-34 \%, 37-41 \%$, $44-46 \%, 51-61 \%, 63-68 \%, 70-72 \%, 80-87 \%$ and $91 \%$. Some flour bags were occasionally transferred from one humidity chamber to another. The moisture content of flour was determined by drying for one hour at $130^{\circ} \mathrm{C}$.

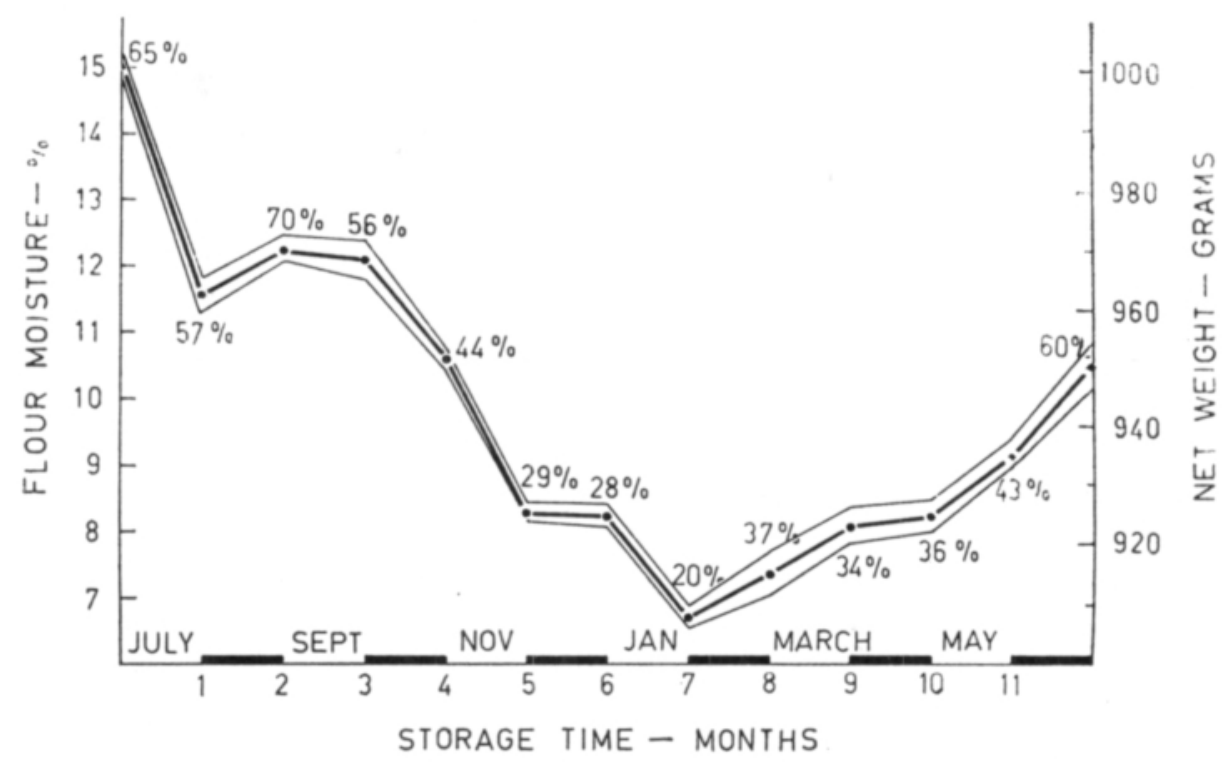

Figure 1. The variation of flour moisture content and net weight during warehouse storage for one year. The corresponding relative humidities are given on the graph. The area between the thin lines represents the magnitude of variation among the ten flour bags studied.

\section{Results and discussion}

Figure 1. shows the average changes in moisture content of ten flour bags stored in the warehouse for one year, starting at the end of July. The relative humidity in the storage room decreased to a minimum of $20 \%$ at the end of January. By that time the flour moisture content had dropped to $6.7 \%$ from the original $15 \%$, representing a decrease of about $9.2 \%$ in net weight. Thereafter the relative humidity increased gradually, approaching the starting value of $65 \%$ at the end of July. During this time, the flour moisture content increased slowly to $10.5 \%$. After 12 months of storage, there had been a considerable total decrease in flour moisture, corresponding to a net weight decrease of about $50 \mathrm{~g}$ from the original $1000 \mathrm{~g}$ at $15 \%$ moisture. These results clearly show that flour tends to dry considerably during normal storage conditions in Finland, the relative humidity in the warehouse rarely reaching the equilibrium humidity value of about $70 \%$ for flour of $15 \%$ moisture content. This is of importance since the quality of flour of low moisture content is affected little even during relatively long periods of storage.

Examples of changes in the flour moisture content during storage at variable relative humidities for a total period of two months are shown in Figure 2. The 


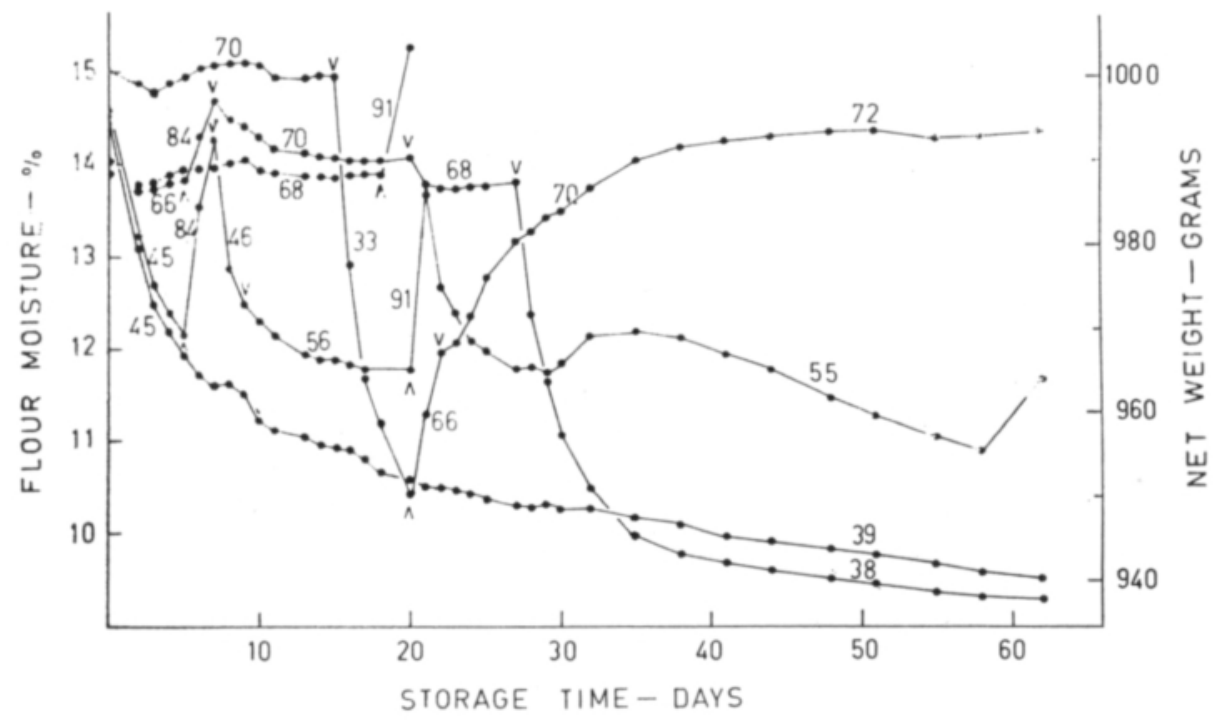

Figure 2. The variation of flour moisture content and net weight during storage at variable relative humidities for two months. The percentile relative humidities for each storage period marked

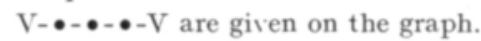

results are in agreement with the observations of earlier workers (ANDERSON 1937, ANker et al. 1942, Bailey 1920, Fairbrother 1929), confirming the observation that the equilibrium humidity for wheat flour of $15 \%$ moisture content is approximately $70 \%$. The results also show, however, that flour which has once dried, reaches only a slightly higher than $14 \%$ moisture level after return to about $70 \%$ relative humidity. A very rapid increase in moisture was observed at about $90 \%$ relative humidity, supporting the observation of FAIRBROTHER (1929). On the other hand, during storage of flour at relatively low relative humidities, $38-39 \%$, a marked drying took place and no equilibrium was reached during 60 days of storage. During this time the moisture content had decreased to about $9.3-9.5 \%$, representing a loss of approximately $5.5 \%$ in net weight. This is a somewhat higher loss of moisture than a decrease from $14 \%$ to about $10.5 \%$ at $36 \%$ relative humidity, as reported by Anker et al. (1942). According to Figure 1., the equilibrium moisture content at $38-39 \%$ relative humidity would be about $8.5-9.0 \%$.

The results show that rapid and marked changes will take place in the moisture content of flour stored at variable relative humidities in standard $1000 \mathrm{~g}$ paper bags. The average storage conditions, even during most of the summer, are such that flour tends to lose moisture. During winter months this loss may be considerable, occasionally resulting in a flour moisture content of less than $7 \%$. On approaching the equilibrium humidity, the net weight of flour follows closely the changes in relative humidity, although, owing to the hysteresis effect, the original moisture level and net weigt of once dried flour may rarely be regained at the normal warehouse relative humidities in Finland. It may also be concluded that the moisture content of flour of about $15 \%$ original moisture is not likely to increase to detrimental levels during 
normal storage in Finland, even if the relative humidity would exceed the critical level of $75-80 \%$ for short periods.

\section{Sum $m$ ary}

Changes in the moisture content of Finnish commercial wheat flour stored at variable relative humidities, representing the conditions typical of flour storage in Finland, were investigated. It could be shown that flour of $15 \%$ moisture at the time of packing tends to dry considerably during normal storage conditions. Owing to the hysteresis effect, the moisture content of once dried flour is not likely to reach detrimental levels during normal storage, even if the relative humidity would exceed the critical level of $75-80 \%$ for short periods. Minimum warehouse relative humidity was observed during Januay, at which time flour moisture had decreased to $6.7 \%$. The equilibrium humidity for flour of $15 \%$ original moisture content was found to be about $70 \%$.

\section{REFERENCES:}

Anderson, J. E. 1937. Equilibrium relative humidities for hard wheat and mill stocks. Northwestern Miller 192: $20-22$.

Anker, C. A., Geddes, W. F. \& Bailey, C. H. 1942. A study on the net weight changes and moisture content of wheat flour at various relative humidities. Cereal Chem. 19: 128-150.

BAввiт, J. D. 1949. Observations on the adsorption of water vapour by wheat. Can. Jour. Research 27 F: $55-72$.

BAILEY, C. H. 1920. The hygroscopic moisture of flour exposed to atmospheres of different relative humidity. Ind. Eng. Chem. 12: 1102-1103.

Borchardt, L. F. 1950. The story of Pyequick. Modern Packaging 23: 121-124, 166.

Coleman, D. A. \& Fellows, H. C. 1925. Hygroscopic moisture of cereals, grains and flaxseed exposed to atmospheres of different relative humidity. Cereal Chem. 2: 275-287.

FAIrbrother, T. H. 1929. The influence of environment on the moisture content of flour and wheat. Cereal Chem. 6: $379-395$.

Linko, P. 1960. Water content and metabolism of wheat during short storage and germination. Ann. Acad. Sci. Fennicae A II 98: 1-69.

\section{SELOSTUS:}

\section{ILMAN SUHTEELLISEN KOSTEUDEN VAIKUTUKSESTA KOTIMAISEN VEHNÄJAUHON KOSTEUSPITOISUUTEEN}

Yu-Yen Linko ja Pekka Linko

Tuotetutkimuslaitos, Vaasan Höyrymylly Osakeyhtiö, Helsinki

Kotimaisen vehnäjauhon kosteuspitoisuuden vaihteluita ilman suhteellisen kosteuden muuttuessa Suomelle tyypillisissä varasto-olosuhteissa on tutkittu. Tutkimuksissa voitiin osoittaa, että jauho, jonka kosteus pakkaushetkellä on noin $15 \%$, pyrkii kuivumaan huomattavasti normaalissa varastointiolosuhteissa. Hystereesi-ilmiöstä johtuen jauhon kosteuspitoisuus ei tyypillisissä varastointiolosuhteissa yleensä pääse kohoamaan haitallisen korkeaksi, vaikka ilman suhteelliren kosteus joksikin aikaa ylittäisikin kriitillisen rajan $75-80 \%$. Varastoilman alhaisin suhteellinen kosteus, $20 \%$, todettiin tammikuussa. Tällöin jauhon kosteuspitoisuus oli laskenut 6,7\%:iin. Jauhon, jonka kosteus pakkaushetkellä on noin $15 \%$, todettiin olevan tasapainotilassa noin $70 \%$ suhteellisessa kosteudessa. 